\title{
Evaluasi Kinerja Guru SMA Bersertifikasi Dengan Model Charlotte Danielson Di SMA Negeri
}

\author{
Erfy Melany Lalupanda \\ Universitas Kristen Wira Wacana Sumba \\ erfy@unkriswina.ac.id \\ Bambang Suteng Sulasmono \\ Universitas Kristen Satya Wacana \\ bambang.sulasmono@staff.uksw.edu \\ Ade Iriani \\ Universitas Kristen Satya Wacana \\ ade.iriani@staff.uksw.edu
}

\begin{abstract}
The research aims to evaluate the performance of certified teachers at SMA Negeri 1 Waingapu, East Sumba Regency. The type of this research is evaluative research. The subject of this research is 7 teachers certified in SMA Negeri 1 Waingapu. The teacher performance evaluation model used is the Charlotte Danielson model that evaluates teacher performance in 4 domains: (1) Planning and Preparation, (2) Classroom Environment, (3) Instruction, and (4) Professional Responsibility. Data collection techniques that used are document studies, observation, and interviews. The data validity test is done by triangulation technique and source. Research result: (1) the performance of certified teachers in SMA Negeri 1 Waingapu, on Planning and Preparation domain, teachers are in proficient category, (2) on Classroom Environment domain, teachers are in basic category, (3) on Instruction domain, teachers are in proficient category, 4) on the domain of Professional Responsibility, teachers are in basic category.
\end{abstract}

Keywords: Certified teacher, Charlotte Danielson Model, Performance Evaluation

\section{Article Info}

Received date: 17 Juni 2019

Revised date: 20 Juni 2019

Accepted date: 25 Juni 2019

\section{PENDAHULUAN}

Guru yang bermutu merupakan ujung tombak peningkatan mutu pendidikan di suatu negara (Guerriero, 2014 : 2; Hightower, et.al, 2011: 2; Goe \& Leslie, 2008 : 2). Guru yang bermutu adalah guru berkinerja tinggi yang mampu memaksimalkan kompetensinya sebagai seorang pendidik.

Kinerja cenderung dipersepsi sebagai tampilan nyata di dunia kerja yang berbasis pada kompetensi yang dimiliki (Danim, 2012:111). Sejalan dengan itu, Mulyasa (2013: 88) juga menyatakan bahwa kinerja merupakan unjuk kerja seseorang yang ditunjukkan dalam penampilan, perbuatan, nilai, dan sikap yang telah dimiliki seseorang. Sehubungan dengan pengertian-pengertian tersebut, jika merujuk pada kinerja seorang guru, maka dapat dipahami bahwa kinerja guru merupakan hasil dari penampilan, perbuatan dan prestasi kerja 
guru dalam menjalankan tugasnya sebagai seorang pendidik, sesuai dengan standar dan kriteria yang telah ditetapkan.

Berbagai upaya yang dilakukan pemerintah untuk meningkatkan mutu pendidikan, tidak akan memberikan sumbangan yang siginifikan, jika tidak didukung oleh mutu guru yang berkinerja tinggi (Lailatussaadah, 2015: 16). Oleh karena itu, sejak tahun 2007 pemerintah Indonesia telah menyelenggarakan program sertifikasi guru setelah diterbitkannya Peraturan Mendiknas Nomor 18 Tahun 2007 tentang Sertifikasi bagi Guru Dalam Jabatan. Program ini bertujuan untuk memberikan pengakuan kepada guru sebagai pendidik profesional.

Pengakuan kedudukan guru sebagai pendidik profesional dibuktikan dengan sertifikat yang diperoleh dari penyelenggara pendidikan dan lembaga pelatihan setelah lulus uji kompetensi yang diselenggarakan oleh satuan pendidikan yang terakreditasi atau lembaga sertifikasi (Mulyasa, 2009:39). Sedang menurut Muslich (2007:2), sertifikasi merupakan proses pemberian sertifikat pendidik kepada guru yang telah memenuhi persyaratan tertentu, yaitu kualifikasi akademik, kompetensi, sehat jasmani dan rohani, serta memiliki kemampuan untuk mewujudkan tujuan pendidikan nasional, yang dibarengi dengan peningkatan kesejahteraan yang layak.

Guru yang sudah berstatus sertifikasi mempunyai hak untuk memperoleh penghasilan dua kali gaji pokok, yaitu tunjangan yang melekat pada gaji, penghasilan lain-lain yaitu berupa tunjangan profesi, tunjangan fungsional, tunjangan khusus, dan tunjangan tambahan yang terkait (Jaedun, 2009:2). Melalui tunjangan sertifikasi ini, pemerintah berharap kesejahteraan guru dapat meningkat, sehingga guru dapat terus melakukan aktualisasi diri sebagai seorang guru profesional yang akan berdampak pada peningkatan kinerja guru dalam melaksanakan proses pembelajaran.

Namun, kenyataan yang terjadi selama lebih dari 10 tahun ini, kinerja guru bersertifikasi di Indonesia belum memberikan hasil yang memuaskan. Hal ini terbukti dari penelitian evaluasi kinerja guru bersertifikasi, oleh World Bank pada tahun 2014 yang menunjukkan bahwa tidak ada perbedaan kinerja antara guru bersertifikat dan guru tidak bersertifikat, yang memberikan bukti lebih lanjut bahwa sertifikasi tidak berdampak pada praktik-praktik pengajaran dan perilaku guru (Chang, et.al, 2014). Selain itu penelitian yang dilakukan oleh Yusrizal (2011), Supriyadi dan Priyastiwi (2014), Murdadi dan Sulistari (2015), serta Agus dkk (2016) menunjukkan bahwa, kinerja guru yang sudah lulus sertifikasi dan sudah menerima tunjangan belum seluruhnya berkinerja tinggi. Berdasarkan penelitian-penelitian tersebut dapat disimpulkan bahwa harapan pemerintah untuk meningkatkan kualitas guru melalui program sertifikasi belum sejalan dengan kenyataan yang terjadi. Terdapat kesenjangan antara kondisi ideal yang diharapkan dari penyelenggaraan program sertifikasi guru dengan fakta yang terjadi di lapangan. Hasilhasil penelitian tersebut menunjukkan bahwa tidak ada perbedaan antara kinerja guru sebelum dan sesudah sertifikasi.

Kondisi demikian juga terjadi dengan guru bersertifikasi di SMA Negeri 1 Waingapu, Kabupaten Sumba Timur, Provinsi Nusa Tenggara Timur. Berdasarkan hasil studi pendahuluan, status sebagai guru bersertifikasi belum memiliki dampak secara linear dengan peningkatan kinerja guru. Meskipun dalam hal ini bukan semua guru, namun secara umum kinerja guru sertifikasi belum menunjukkan hasil yang menggembirakan. Kinerja guru bersertifikasi di SMA Negeri 1 Waingapu jika dilihat dari aspek perencanaan pembelajaran, menunjukkan bahwa masih ada guru sertifikasi yang tidak memiliki perangkat pembelajaran 
yang lengkap, baik dari segi kelengkapan administrasi maupun kelengkapan substansi. Menurut Kepala Sekolah, guru hanya sekedar membuat perangkat pembelajaran dan tidak memahami pedoman penyusunan perangkat pembelajaran yang sesuai dengan struktur kurikulum. Selain itu kepala Sekolah juga menyatakan bahwa, budaya baca guru-guru di SMA Negeri 1 Waingapu masih rendah, sehingga menyebabkan masih ada guru yang belum bisa membuat silabus, Rencana Pelaksanaan Pembelajaran (RPP) dan bahan ajar sendiri, namun hanya copy paste dari internet atau dari rekan guru yang mengajar mata pelajaran yang sama.

Pada aspek pelaksanaan pembelajaran, masih ada guru yang tidak menyampaikan apersepsi dan tujuan pembelajaran pada kegiatan pendahuluan (guru langsung menyampaikan materi pembelajaran).Selain itu masih ada guru yang melaksanakan pelaksanaan pembelajaran tidak sesuai dengan RPP yang sudah dirancang. Maksudnya, perangkat pembelajaran sudah menggunakan kurikulum 2013, namun pembelajaran di kelas belum menunjukkan implementasi Kurikulum 2013. Selain itu ada kegiatan-kegiatan dalam RPP yang tidak dilaksanakan saat pembelajaran dikelas atau sebaliknya. Namun, kepala sekolah menyatakan bahwa hal ini terjadi karena Kurikulum 2013 masih merupakan hal yang baru, sehingga guru-guru masih membutuhkan waktu untuk penyesuain dalam implementasinya.

Pada aspek penilaian pembelajaran, belum semua guru memahami tentang penilaian otentik. Kepala sekolah menyatakan bahwa sekolah ini baru memasuki tahun kedua pelaksanaan Kurikulum 2013, sehingga meskipun guru yang sudah menjalani proses sertifikasi sekalipun masih mengalami kesulitan dalam melakukan penilaian otentik. Sehingga, berdasarkan hasil studi pendahuluan ini, SMA Negeri 1 Waingapu memerlukan evaluasi kinerja guru secara eksternal untuk mengetahui gambaran nyata dan menyeluruh dari kinerja guru bersertifikasi di sekolah tersebut.

Sistem evaluasi guru sangat bergantung pada pengamatan kelas yang dilakukan oleh kepala sekolah atau pengawas sekolah. Evaluasi yang dilakukan berbasis observasi, dan melibatkan pengumpulan data berkelanjutan menggunakan instrumen evaluasi. Persyaratan instrumen evaluasi kinerja guru harus memenuhi ukuran atau standar tertentu, yang artinya evaluasi kinerja dilakukan sesuai dengan indikator kinerja yang telah ditetapkan berdasarkan kriteria kinerja yang diadopsi sekolah dan kabupaten untuk menentukan keefektifan kinerja guru. Evaluasi guru yang efektif sangat penting untuk memverifikasi dan mempertahankan pengajaran berkualitas tinggi dan untuk memastikan bahwa tujuan pembelajaran tercapai (Phillips,et.al, 2014: 2).

Kinerja guru yang sudah bersertifikasi perlu dievaluasi secara periodik. Melalui program evaluasi dapat diketahui sejauh mana kinerja guru bersertifikasi dalam melaksanakan tugas dan tanggungjawabnya. Penelitian evaluasi kinerja guru melibatkan pengumpulan data dengan menggunakan instrumen evaluasi. Persyaratan instrumen evaluasi kinerja guru harus memenuhi ukuran atau standar tertentu.

Penelitian ini mengukur kinerja guru yang sudah bersertifikasi menggunakan model evaluasi yang di kembangkan oleh Charlotte Danielson. Alasan pemilihan model ini yaitu pertama, model ini menggambarkan pentingnya memiliki kerangka evaluasi kinerja guru yang komprehensif. Model ini menilai kinerja guru terhadap seperangkat standar kinerja yang telah ditentukan yang diterjemahkan ke dalam deskriptor rinci dalam rubrik. Kedua, model ini cocok untuk menilai kinerja guru sertifikasi (Moss, 2015: 64-67), dan ketiga, model ini telah banyak digunakan oleh negara-negara maju seperti Amerika Serikat. Sehingga dalam era persaingan mutu 
pendidikan di era ini, Indonesia perlu menggunakan alat evaluasi yang sama seperti yang digunakan di negara maju.

Charlotte Danielson merupakan seorang pendidik dan konsultan pendidikan di Amerika. Charlotte Danielson diakui di bidang penilaian keefektifan guru yang memiliki spesialisasi dalam desain sistem evaluasi guru, sekaligus memastikan kualitas guru. Model evaluasi kinerja guru Charlotte Danielson menjelaskan pentingnya membimbing dan mengembangkan praktik profesional guru melalui kerangka pengajaran.

Model ini mempertimbangkan komponen dan elemen yang dibutuhkan dalam evaluasi kinerja guru dalam bentuk kerangka pengajaran. Kerangka dirancang untuk memberikan panduan bagi guru, kepala sekolah maupun pengawas dalam pengembangan praktik profesional guru (Erasmus dan Nicola, 2015: 68). Kerangka pengajaran ini dapat digunakan sebagai peta atau garis besar bagi guru dan evaluator untuk evaluasi kinerja guru, berupa diskusi terstruktur, praktik reflektif, dan penetapan tujuan (Moss, 2015: 18).

Tindakan yang dapat dilakukan guru untuk memperbaiki pembelajaran siswa diidentifikasi dengan jelas dalam kerangka pengajaran ini. Model kerangka pengajaran Danielson dibagi dalam 4 domain, yaitu Domain 1: Persiapan dan Perencanaan, Domain 2: Pengelolaan Kelas, Domain 3: Pelaksanaan pembelajaran, dan Domain 4: Tanggungjawab profesional. Setiap domain terdiri dari 5 atau 6 komponen, sehingga semuanya berjumlah 22 komponen. Setiap komponen dinilai berdasarkan 4 penilaian, yaitu Unsatisfactory (kurang baik), Basic (cukup baik), Proficient (Baik), Distinguished (sangat baik).

Berdasarkan paparan diatas, peneliti melakukan penelitian evaluasi guru bersertifikasi di SMA Negeri 1 Waingapu, Kabupaten Sumba Timur menggunakan model evaluasi kinerja mengajar Guru versi Charlotte Danielson.

\section{METODE PENELITIAN}

Penelitian ini merupakan penelitian evaluatif dengan pendekatan kuantitatif sederhana dan kualitatif. Penelitian ini di lakukan di SMA Negeri 1 Waingapu, Kabupaten Sumba Timur. Subyek penelitian adalah 7 orang guru bersertifikasi yang mengajar mata pelajaran bahasa inggris, matematika, bahasa Indonesia, kimia, biologi, sosiologi dan sejarah. Waktu pelaksanaan penelitian adalah November-Desember 2017. Teknik pengumpulan data menggunakan rubrik evaluasi kinerja guru Charlotte Danielson. Hasil yang diperoleh dari rubrik tersebut dipertegas melalui hasil studi dokumen, wawancara dan observasi. Keabsahan data menggunakan teknik trianggulasi sumber dan trisngulasi teknik.

\section{HASIL PENELITAN DAN PEMBAHASAN \\ Hasil Penelitan}

Hasil penelitian evaluasi kinerja guru bersertifikasi di SMA Negeri 1 Waingapu adalah sebagai berikut.

\section{Persiapan dan Perencanaan Pembelajaran}

Hasil penelitian pada domain Perencanaan Pembelajaran menunjukkan bahwa kinerja guru bersertifikasi sudah berada pada kategori baik dinilai dari penguasaan pedagogi dan konten yang akan diajarkan, penyusunan tujuan pembelajaran, penyiapan sumber belajar, merancang pembelajaran yang koheren dan menyusun penilaian hasil belajar siswa. Namun masih berada pada kategori cukup baik dinilai dari pengetahuan guru tentang karakteristik siswa

Evaluasi Kinerja Guru domain persiapan dan perencanaan pembelajaran berdasarkan rubrik evaluasi Charlotte Danielson disajikan pada tabel berikut. 
Tabel 1. Kinerja Guru Bersertifikasi pada Domain persiapan dan perencanaan pembelajaran

\begin{tabular}{lcc}
\hline \multicolumn{1}{c}{ Komponen } & $\begin{array}{c}\text { Kinerja } \\
\text { Guru }\end{array}$ & Keterangan \\
\hline 1.a Pengetahuan guru tentang pedagogi dan konten materi yang akan diajarkan & 3 & Baik \\
\hline 1b. Pengetahuan guru tentang karakteristik siswa & 2 & Cukup Baik \\
\hline 1c. Guru menyusun tujuan Pembelajaran & 3 & Baik \\
\hline 1d. Pengetahuan guru tentang penggunaan sumber belajar & 3 & Baik \\
\hline Ie. Merancang pembelajaran yang koheren & 3 & Baik \\
\hline If.Merancang penilaian hasil belajar siswa & 3 & Baik \\
\hline
\end{tabular}

Sumber: Data penelitian

Tabel 1 diatas menunjukkan bahwa pada domain persiapan dan perencanaan pembelajaran guru sudah berkinerja baik.

Berdasarkan hasil studi dokumen berupa RPP dan Silabus, guru menunjukkan pengetahuan yang sangat baik dan luas tentang konsep-konsep penting dan struktur materi yang akan diajarkan dan bagaimana konsepkonsep tersebut berhubungan satu sama lain maupun dengan materi lainnya. Guru juga memaparkan struktur kurikulum (standar kompetensi, kompetensi dasar, indikator dan penyajian materi ajar) dalam Rencana Pelaksanaan Pembelajaran (RPP) dengan jelas. Selain itu guru menunjukkan pengetahuan yang baik tentang hubungan prasyarat antara konten materi yang akan diajarkan kepada siswa yang nampak pada urutan penyajian materi dalam RPP dan apersepsi saat pembelajaran di kelas.

Berdasarkan hasil observasi kelas guru juga menunjukkan pengetahuan dan keterampilan tentang berbagai pendekatan pedagogis yang digunakan dalam pembelajaran, yaitu model, strategi, dan metode pembelajaran yang sesuai dengan materi yang diajarkan.

Hasil ini ditegaskan dalam wawancara guru MW, yang menyatakan bahwa:

"Hal-hal yang harus dipersiapakan sebelum membuat RPP, yaitu dengan mempersiapkan seperti program semester, program tahunan, analisis silabus, penilaian, urutan penyajian materi setiap KD dan alokasi waktu pelaksanaannya disertai model, metode, dan media pembelajaran yang digunakan. Selain itu penilaian, program remedial juga harus dirancang. Setelah itu baru action di kelas" (Wawancara tanggal 14 November 2017).
Selain itu guru NK juga menyatakan hal yang hampir sama, bahwa:

"Sebelum pelaksanaan pembelajar an terlebih dahulu saya akan melakukan analisis hubungan keterkaitan Standar Kompetensi Lulusan (SKL) dengan Kompetensi Inti (KI) dan Kompetensi Dasar (KD), lalu setelah itu membuat silabus, menentukan IPK (Indikator Pencapaian Kompetensi), Kriteria Ketuntasan Minimal (KKM), membuat Kalender Pendidikan, Program Semester, Program Tahunan. Selanjutnya membuat Rencana Pelaksanaan Pembelajar an (RPP), yang substansinya mencakup Kompetensi Inti (KI), Kompetensi Dasar (KD), indikator, tujuan pembelajaran, urutan penyajian materi, kegiatan pembelajaran, pendekatan pembelajaran, model pembelajaran, metode pembelajaran, dan penilaian" (Wawancara tanggal 13 November 2017).

Pernyataan ini diperkuat dengan pernyataan Kepala Sekolah yang menyatakan bahwa:

"Ada namanya analisis SKL, KI dan KD. Dari pusat sudah menyiapkan silabus. Namun silabus yang digodok berdasarkan analisis itu lain. Artinya ada adaptasi. Karena yang menyusun dari pusat itu kan pakar. Sedangkan kita orang lapangan. Pasti ada benturan-benturan. Analisis akan turun pada prota, promes silabus, dan silabus akan turun jadi RPP" (Wawancara tanggal 27 November 2017).

Hasil-hasil wawancara tersebut menunjukkan bahwa guru memiliki kompetensi pedagogik yang baik dalam persiapan dan perencancaan pembelajaran.

Guru yang berada pada kategori baik menyajikan tujuan pembelajaran pada RPP yang mencerminkan nilai, urutan dan keselarasan dengan urutan kegiatan 
pembelajaran dan keterkaitan dengan materi yang telah dipelajari. Artinya guru sudah merancang kegiatan pembelajaran dengan akurat dan lengkap. Hal ini mengindikasikan bahwa guru memahami tujuan dari pembelajaran yang akan dilakukan. Tujuan pembelajaran disusun dengan jelas dan menggunakan metode penilaian yang jelas. Tujuan pembelajaran yang disusun juga mencerminkan keseimbangan antar aspek hasil pembelajaran, yaitu hasil pembelajaran ranah kognitif, afektif dan psikomotor.

Guru yang berada pada kategori baik, sudah menyusun kegiatan pembelajaran yang melibatkan partisipasi aktif siswa dengan baik, melalui tanya jawab interaktif dan diskusi. Guru juga menyusun struktur pembelajaran yang jelas dan perkembangan kegiatan terorganisir dengan alokasi waktu yang wajar. Selain itu guru juga menggunakan berbagai media pembelajaran, termasuk penggunaan TIK, berupa PPT, video, dan audio.

Hasil ini dipertegas dengan pernyataan Kepala Sekolah, yang menyatakan bahwa:

"Media yang paling sederhana itu papan tulis. Lalu media canggih seperti LCD dan internet. Guru-guru disini sudah banyak yang terampil menggunakan media pembelajaran" (Wawancara tanggal 27 November 2017).

Hasil wawancara tersebut menunjukkan bahwa guru memiliki keterampilan yang baik dalam menggunakan media pembelajaran.
Guru juga menunjukkan pengetahuan tentang penggunaan sumber belajar dengan baik, baik untuk sumber belajar yang digunakan di dalam kelas maupun penggunaan sumber belajar untuk meningkatkan pengetahuan guru dan siswa. Selain itu guru juga menggunakan beberapa sumber daya eksternal seperti internet sebagai referensi tambahan sumber belajar.

Hasil studi dokumen, wawancara dan observasi pada domain persiapan dan perencanaan pembelajaran ini mempertegas hasil evaluasi kinerja guru bersertifikasi dengan rubrik evaluasi Charlotte Danielson.

\section{Pengelolaan Kelas}

Hasil penelitian pada domain pengelolaan kelas menunjukkan bahwa kinerja guru bersertifikasi berada pada kategori baik dinilai dari segi cara guru mengelola prosedur kelas. Namun, berada pada kategori cukup baik pada cara guru menciptakan lingkungan belajar yang saling menghormati, antara guru dengan siswa dan antara siswa dengan siswa lainnya, menciptakan budaya belajar dalam kelas, memantau perilaku siswa dan mengatur ruang kelas secara fisik.

Evaluasi Kinerja Guru pada domain pengelolaan kelas berdasarkan rubrik evaluasi Charlotte Danielson disajikan pada tabel 2 berikut.

Tabel 2 Kinerja Guru Bersertifikasi pada Domain Pengelolaan Kelas

\begin{tabular}{lcc}
\hline \multicolumn{1}{c}{ Komponen } & Kinerja Guru & Keterangan \\
\hline $\begin{array}{l}\text { 2a.Menciptakan lingkungan dan suasana belajar yang saling } \\
\text { menghormati antara guru dengan siswa dan antara siswa dengan } \\
\text { siswa lainnya. }\end{array}$ & 2 & Cukup Baik \\
\hline 2b.Menciptakan budaya belajar dalam kelas & 2 & Cukup Baik \\
\hline 2c.Mengelola prosedur kelas & 3 & Baik \\
\hline 2d.Memantau perilaku siswa & 2 & Cukup Baik \\
\hline 2e.Mengatur penataan ruang kelas secara fisik & 2 & Cukup Baik \\
\hline
\end{tabular}

Tabel 2 diatas menunjukkan bahwa pada domain pengelolaan kelas guru berkinerja cukup baik.
Berdasarkan hasil observasi, guru tidak memanfaatkan alokasi waktu secara efisien. Akibat terlalu lama menunggu siswa 
yang hendak ke depan kelas untuk menjelaskan materi yang menjadi tugasnya, ada banyak waktu yang terbuang. Guru umumnya menyadari dan memantau perilaku siswa, tetapi hanya beberapa siswa saja yang terpantau oleh guru.

Hasil ini dipertegas dengan hasil wawancara dengan Kepala Sekolah yang menyatakan bahwa:

"Guru kurang bisa memanajemen waku. Guru merancang 3 jam pembelajaran, namun saat pelaksanaan beberapa hal yang sudah direncanakan tidak terlaksana. Hal itu terjadi karena guru belum mampu menjadi moderator yang baik." (Wawancara tanggal 27 November 2017).

Hasil wawancara menunjukkan bahwa guru tdak cukup baik dalam mengelolah waktu pembelajaran di kelas.

Selain itu, hanya beberapa siswa menunjukkan harapan yang tinggi terhadap hasil pembelajaran, aktivitas pembelajaran, tugas, dan interaksi kelas yang mereka lakukan. Siswa bertanggungjawab mengerjakan tugas, tetapi hanya sedikit yang mementingkan kualitas. Hal ini teramati saat guru menyampaikan kepada siswa tentang pentingnya materi yang dipelajari, siswa terkesan tidak memiliki ketertarikan. Saat disuruh maju oleh guru untuk menyampaikan materi, hampir semua siswa tidak siap. Hanya beberapa siswa yang bersedia, namun membutuhkan waktu yang agak lama sampai siswa benar-benar menyajikan materi. Hal ini juga menunjukkan bahwa siswa memiliki harapan yang sederhana terhadap aktivitas pembelajaran dan penugasan yang mereka lakukan. Selain itu respon siswa juga menunjukkan bahwa siswa hanya memiliki sedikit kebanggaan terhadap tugas mereka. Mereka tampaknya termotivasi oleh keinginan untuk sekedar menyelesaikan tugas daripada mengerjakan tugas yang berkualitas.

Hasil studi dokumen, wawancara dan observasi pada domain pengelolaan kelas ini mempertegas hasil evaluasi kinerja guru bersertifikasi dengan rubrik evaluasi Charlotte Danielson bahwa kinerja guru pada domain ini masih berada pada kategori cukup baik.

\section{Pelaksanaan Pembelajaran}

Hasil penelitian pada domain pelaksanaan pembelajaran menunjukkan bahwa kinerja guru bersertifikasi sudah berada pada kategori baik dinilai dari komunikasi guru dengan siswa dalam menjelaskan materi dan mengarahkan siswa baik secara lisan maupun tertulis, menggunakan teknik tanya jawab dan diskusi, melibatkan partisipasi siswa dalam pembelajaran melalui penugasan, presentasi, dan kerja kelompok, menggunakan penilaian proses pembelajaran dan responsif dalam pembelajaran (cepat tanggap).

Evaluasi Kinerja Guru domain pelaksanaan pembelajaran berdasarkan rubrik evaluasi Charlotte Danielson disajikan pada tabel berikut.

Tabel 3 Kinerja Guru Bersertifikasi pada Domain Pelaksanaan Pembelajaran

\begin{tabular}{lcc}
\hline \multicolumn{1}{c}{ Komponen } & Kinerja Guru & Keterangan \\
\hline 3a.Komunikasi guru dan siswa dalam pembelajaran & 3 & Baik \\
\hline 3b.Penggunaan teknik tanya jawab dan diskusi dalam pembelajaran & 3 & Baik \\
\hline 3c.Melibatkan partisipasi siswa dalam pembelajaran & 3 & Baik \\
\hline 3d.Menilai proses pembelajaran & 3 & Baik \\
\hline 3e.Responsif (cepat tanggap) dalam pembelajaran & 3 & Baik \\
\hline Sumber: Data penelitian & &
\end{tabular}

Tabel 3 diatas menunjukkan bahwa pada domain pelaksanaan pembelajaran guru sudah berkinerja baik.
Berdasarkan hasil observasi, guru menyampaikan tujuan pembelajaran, arah dan prosedur pembelajaran dengan baik. Penjelasan guru tentang konsep yang diajarkan jelas dan 
sesuai dan dapat dihubungkan dengan pengetahuan dan pengalaman siswa. Guru menggunakan bahasa lisan dan tertulis dengan baik guru dan sesuai dengan bahasa indonesia yang baik dan benar dan menggunakan kosakata yang tepat dan sesuai dengan pemahaman siswa.

Kegiatan belajar dan penugasan disesuaikan dengan perkembangan belajar siswa, dan hampir semua siswa terlibat aktif dalam mengeksplorasi konsep. Kelompok belajar yang dibentuk guru produktif dan sepenuhnya sesuai dengan karakteristik siswa dan tujuan pembelajaran yang akan dicapai. Guru membagi kelompok diskusi dalam kelas dengan membaurkan anak-anak yang biasanya aktif dan pasif, jadi dalam setiap kelompok ada macam-macam anak, sehingga anak-anak yang aktif dapat membantu temannya.

Hasil ini dipertegas dengan wawancara dengan guru NK yang menyatakan bahwa:

"Saya mengelolah pembagian kelompok diskusi dalam kelas itu dengan membaurkan anak-anak yang aktif, jadi dalam setiap kelompok ada macam-macam kelompok anak, sehingga yang anak-anak yang aktif dapat membantu temannya" (Wawancara tanggal 13 November 2017).

Guru SP dan MW juga menegaskan pernyataan tersebut, dengan menyatakan bahwa:

"Jadi kalau saya biasanya membagi kelompok dengan menggabungkan antara anak yang bisa dan tidak bisa. Untuk transisi kegiatan pembelajaran saya tegas, sehingga tujuan pembelajaran hari itu tercapai" (Wawancara guru SP tanggal 06 November 2017).

"Pembagian kelompok di acak antara siswa kelompok atas, kelompok tengah dan kelompok bawah" (Wawancara guru MW tanggal 14 November 2017).

Hasil wawancara tersebut menunjukkan bahwa guru dapat mengenal perkembangan belajar siswa.
Guru dapat menyesuaikan transisi kegiatan pembelajaran dengan alokasi waktu yang sudah direncanakan, sehingga waktu transisi setiap kegiatan berjalan sesuai alokasi waktunya. Namun, kadang-kadang waktu pembelajaran agak lambat, karena ada satu dan lain hal seperti pengaturan kelas untuk diskusi kelompok, pemasangan LCD, dan hal-hal lain.

Hasil ini dipertegas dengan wawancara dengan guru NK yang menyatakan bahwa:

"Kalau transisi kegiatan pembelajaran ya harus disesuaikan dengan alokasi waktu yang sudah direncanakan, sehingga waktu transisi setiap kegiatan pas. Namun, kadangkadang waktu pembelajaran agak molor, karena ada satu dan lain hal seperti pengaturan kelas untuk diskusi kelompok, pemasangan LCD" (Wawancara tanggal 13 November 2017).

Hasil wawancara tersebut menunjukkan bahwa guru dapat menyesuaikan transisi waktu dalam pelaksanaan pembelajaran

Guru yang berada pada kategori baik, membuat siswa sepenuhnya menyadari kriteria, standar kinerja dan teknik penilaian yang digunakan guru dalam pelaksanaan pembelajaran yang dilakukan. Artinya guru sudah menyampainkan kriteria penilaian, dengan jelas kepada siswa. Guru juga memonitor proses belajar setiap kelompok siswa dikelas. Guru mampu membuat penyesuaian kecil dalam aktivitas pembelajaran ketika situasi kelas berubah, dan penyesuaian berjalan lancar. Guru berhasil mengakomodasi pertanyaan siswa, dan guru mencari pendekatan yang tepat untuk siswa yang mengalami kesulitan belajar.

Hasil studi dokumen, wawancara dan observasi pada domain pelaksanaan pembelajaran ini mempertegas hasil evaluasi kinerja guru bersertifikasi dengan rubrik evaluasi Charlotte Danielson, bahwa kinerja Guru bersertifikasi dalam pelaksanaan pembelajaran termasuk kategori baik. 


\section{Tanggungjawab Profesional}

Hasil penelitian pada domain tanggungjawab profesional menunjukkan bahwa kinerja guru bersertifikasi berada pada kategori baik dinilai dari kemampuan mereka membuat catatan yang akurat mengenai kehadiran, hasil belajar dan kemajuan belajar siswa; dan menunjukkan profesionalitas lewat sikap etis dan integritas sebagai pendidik. Namun, berada pada kategori cukup baik dinilai dari kemampuan guru dalam merefleksikan pengajaran dengan melakukan evaluasi diri, berkomunikasi dengan orang tua/wali siswa, berpartisipasi dalam komunitaskomunitas profesional, dan mengembangkan profesionalismenya.

Evaluasi Kinerja Guru domain tanggungjawab profesional berdasarkan rubrik evaluasi Charlotte Danielson disajikan pada tabel berikut.

Tabel 4 Kinerja Guru Bersertifikasi pada Domain Tanggungjawab Profesional

\begin{tabular}{|c|c|c|}
\hline Komponen & $\begin{array}{c}\text { Kinerja } \\
\text { Guru }\end{array}$ & Keterangan \\
\hline 4a.Merefleksikan pembelajaran yang telah dilakukan dengan melakukan evaluasi diri & 2 & Cukup Baik \\
\hline 4b.Membuat catatan pelaksanaan pembelajaranyang akurat & 3 & Baik \\
\hline 4c.Komunikasi guru dengan orang tua/wali siswa & 2 & Cukup Baik \\
\hline 4d.Partisipasi guru dalam komunitas professional & 2 & Cukup Baik \\
\hline 4e.Pengembangan Profesionalisme & 2 & Cukup Baik \\
\hline 4f.Menunjukkan profesionalitas & 3 & Baik \\
\hline
\end{tabular}

Sumber: Data penelitian.

Tabel 4 diatas menunjukkan bahwa pada domain tanggungjawab profesional guru berkinerja cukup baik.

Berdasarkan studi dokumen, guru melakukan evaluasi diri tentang efektivitas pelaksanaan pembelajaran dan ketercapaian tujuan pembelajaran, namun kesannya masih bersifat umum dan tidak akurat. Guru memiliki catatan kehadiran, catatan perilaku siswa, penyelesaian tugas, proses dan hasil belajar siswa, namun tidak akurat.

Selain itu guru jarang berkomunikasi dengan orang tua siswa, karena perkembangan belajar siswa biasanya disampaikan pada wali kelas dan guru BK. Hanya masalah yang sangat urgen yang membuat guru harus berkomunikasi dengan orang tua siswa.

Hasil ini dipertegas dengan wawancara guru NH yang menyatakan bahwa:

\footnotetext{
"Saya sering mengkomunikasikan perkembangan siswa kepada wali kelas dan guru BK. Namun kalau memang masalahnya sangat urgen maka saya akan menghubungi orang tuanya" (Wawancara tanggal 07 November 2017)
}

Pernyataan dari guru RB juga demikian, bahwa:

"Saya langsung ke wali kelas ya kalau ada yang bermasalah. Sehingga kalau sudah sangat terlalu, maka akan dipanggil orang tuanya" (Wawancara tanggal 08 November 2017

Hasil wawancara tersebut menunjukkan bahwa guru berkomunikasi langsung dengan orang tua/wali siswa.

Guru cukup aktif dalam kegiatankegiatan MGMP dan pelatihan-pelatihan yang diadakan sekolah maupun provinsi. Namun, guru aktif dalam kegiatan sekolah seperti menjadi Pembina ekstra kurikuler. Selain itu guru cukup aktif meningkatkan profesionalismenya lewat pelatihan-pelatihan maupun membantu rekan guru lain untuk meningkatkan profesionalisme mereka.

Hasil ini sesuai dengan hasil wawancara dengan guru NH yang menyatakan bahwa:

"Saya mengikuti MGMP, namun tidak terlalu aktif karena ada kendalakendala." (Wawancara tanggal 07 November 2017) 
Guru RB juga menyatakan bahwa: "Saya cukup aktif dalam kegiatan MGMP atau pelatihan-pelatihan. Namun, memang ya belum banyak ya diadakan pelatihanpelatihan. Sebenarnya saya ingin sekali mengikuti pelatihan-pelatihan, namun ya karena keterbatasan waktu dan juga biasanya hanya guru tertentu yang dipilih untuk mengikuti pelatihan. Tapi kalau diberi kesempatan saya mau sekali ikut"(Wawancara tanggal 08 November 2017)

Selain itu guru WP juga menambahkan, bahwa:

"Ya saya cukup aktif dalam kegiatan MGMP sebagai anggota. Selain itu saya Pembina PMR" (Wawancara tanggal 10 November 2017).

Hasil wawancara tersebut menunjukkan bahwa guru belum teralu aktif dalam kegiatankegiatan pengembangan profesinalisme sebagai guru yang sudah bersertifikasi.

Hasil studi dokumen, wawancara dan observasi pada domain tanggungjawab profesional ini mempertegas hasil evaluasi kinerja guru bersertifikasi dengan rubrik evaluasi Charlotte Danielson bahwa kinerja guru bersertifikasi pada domain tanggungjawab profesional termasuk kategori cukup baik.

\section{Pembahasan}

\section{Persiapan dan Perencanaan Pembelajaran}

Menurut Danielson (2007:1) langkah awal sebelum masuk kelas, tidak hanya perencanaan, namun dibutuhkan juga persiapan yang baik. Sehingga pada domain 1 dari model evaluasi Danielson ini menilai persiapan dan perencanaan pembelajaran yang dilakukan guru. Langkah pertama yang harus dilakukan sebelum kegiatan pembelajaran di kelas adalah perencanaan dan persiapan pembelajaran yang efektif. Perencanaan dan persiapan bukan hanya sekedar merancang kegiatan belajar mengajar, namun guru juga harus memiliki pengetahuan tentang karakteristk siswa dan sumber daya pembelajaran yang tersedia dan kesesuaiannya dengan materi yang akan diajarkan. Selain itu pengetahuan guru akan pedagogi dan konten juga sangat penting untuk menyusun tujuan, kegiatan dan penilaian pembelajaran.

Berdasarkan hasil penelitian, guru bersertifikasi di SMA Negeri 1 Waingapu sudah berkategori baik pada domain persiapan dan perencanaan. Hal ini disebabkan guru-guru tersebut merupakan golongan guru yang dapat merespon dan memahami perubahan struktur kurikulum dan mampu mengimplementasikan kurikulum baru tersebut dalam perangkat pembelajaran sebagai perencanaan dan persiapan pembelajaran.

\section{Pengelolaan Kelas}

Tugas dan Tanggungjawab guru tidak hanya berkutat dengan menyusun perencanaan dan persiapan pembelajaran dan melaksanakan pembelajaran, tetapi guru juga dituntut untuk memiliki keterampilan mengelola kelas, karena interaksi guru dengan siswa dan kegiatan pembelajaran terjadi di kelas.

Melalui keterampilan pengelolaan kelas juga, guru dapat mengontrol kelas jika terjadi gangguan dalam proses belajar. Pengelolaan kelas merupakan syarat mutlak bagi terjadinya proses pembelajaran yang efektif. Kondisi yang kondusif untuk belajar akan terwujud jika guru mengatur kelas, siswa dan sarana dan prasarana yang ada di kelas dengan sangat baik, serta mengendalikan suasana pembelajaran di kelas kedalam suasana yang menyenangkan (Kadir, 2014: 25-26).

Setelah siswa tumbuh dewasa siswa akan mengingat bagaimana guru memperlakukan mereka saat di kelas. Siswa akan mengingat guru favorit mereka yang memiliki selera humor, guru yang menyajikan pembelajaran yang relevan, guru yang selalu memberi pujian, guru yang menghargai dan menghormati keberadaan siswa serta guru yang memberikan rasa aman kepada siswa. Namun, guru juga harus mengetahui bahwa siswa juga akan mengingat guru yang meremehkan usaha 
siswa dan guru yang menciptakan suasana takut selama pembelajaran (Danielson, 2007:27).

Hasil penelitian evaluasi kinerja guru bersertifikasi di SMA Negeri 1 Waingapu pada yang berada pada kategori cukup baik. Hasil ini menunjukkan bahwa guru-guru di sekolah ini sebenarnya memiliki pengetahuan dan kesadaran tentang keterampilan dalam menciptakan dan mengendalikan situasi kelas. Namun, dalam pelaksanaannya guru-guru tersebut belum cukup mampu memelihara dan memusatkan perhatian siswa saat pembelajaran, karena banyak siswa yang tidak fokus dalam pembelajaran dan membuat kegaduhan dengan bercerita dengan rekannya saat pembelajaran berlangsung. Guru juga belum cukup mampu mengatasi siswa-siswa yang membuat pelanggaran, seperti bolos atau terlambat masuk kelas. Selain itu, guru juga belum menata kelas, agar siswa dapat belajar dengan nyaman. Guru hanya tergantung dengan tatanan kelas pada umumnya, padahal cuaca di Kota Waingapu yang sangat panas, dapat menyebabkan ketidaknyamanan siswa dalam belajar.

Menurut Mulyasa (2007:91) guru yang dapat mengelola kelas dengan baik merupakan guru profesional yang memiliki keterampilan pengelolaan kelas dalam menciptakan iklim pembelajaran yang kondusif dan dapat mengendalikannya jika terdapat gangguan selama kegiatan pembelajaran. Selain itu guru dituntut untuk menciptakan suasana belajar yang menyenangkan. Jika suasana pembelajaran tidak menyenangkan kondisi kelas yang aktif, kreatif, dan efektif tidak akan tercipta.

\section{Pelaksanaan Pembelajaran}

Domain pelaksanaan pembelajaran merupakan aktivitas pembelajaran yang sebenarnya, karena domain ini melaksanakan apa yang sudah direncanakan dan dipersiapkan pada domain 1 dan memanfaatkan pengelolaan kelas pada domain 2 untuk mencapai tujuan pembelajaran (Danielson, 2007:48). Hasil evaluasi kinerja guru pada domain pelaksanaan pembelajaran sudah berada pada kategori baik. Guru sudah mampu melaksanakan pembelajaran dengan baik dalam menjelaskan materi kepada siswa secara lisan maupun tertulis, menggunakan metode pembelajaran dan teknik tanya jawab atau diskusi yang melibatkan partisipasi aktif siswa dalam pembelajaran, penugasan, presentasi, dan kerja kelompok. Selain itu guru juga mampu melaksanakan pembelajaran yang efektif, efisien, dan sesuai dengan perkembangan teknologi.

\section{Tanggungjawab Profesional}

Pada prinsipnya tugas guru tidak hanya mengajar dan mendidik, tetapi melakukan seperangkat tugas yang berkaitan dengan kegiatanpengembangan profesionalisme guru sebagai seorang pendidik. Guru sebagai pendidik profesional harus memiliki keahlian dalam melaksanakan tugasnya. Oleh karena itu untuk dapat melaksanakan tugasnya, guru dituntut untuk terus menerus secara berkelanjutan meningkatkan kompetensinya, agar tujuan pembelajaran yang efektif yang akan berdampak pada peningkatan mutu pendidikan akan tercapai.

Guru yang profesional menunjukkan komitmen mereka sebelum, selama dan setelah pembelajaran. Domain tanggungjawab profesional yang di kembangkan oleh Charlotte Danielson fokus pada tindakan guru setelah pembelajaran. Menurut Danielson 2007: 69), guru yang memiliki tanggungjawab profesional adalah guru yang mampu melakukan refleksi atau evaluasi diri untuk memperbaiki dan meningkatkan pembelajaran selanjutnya, guru yang memiliki catatan akurat tentang siswa, guru yang berkomunikasi dengan orang tua tentang perkembangan dan kondisi belajar siswa, guru yang bisa menerima saran dan kritik dari rekan-rekannya, dan guru yang terus berusaha meningkatkan kompetensi pedagogik dan profesionalnya untuk pengembangan diri yang berkelanjutan. 
Hasil evaluasi kinerja guru bersertifikasi di SMA Negeri 1 Waingapu pada domain tanggungjawab profesional, berada pada kategori cukup baik. Hasil ini menunjukkan guru sudah, menyadari tentang tugas dan tanggungjawabnya sebagai seorang pendidik yang profesional, namun dalam pelaksanaanya, guru kurang aktif berpartisipasi dalam kegiatan sekolah, daerah, dan komunitas profesional. Padahal, guru yang sudah bersertifikasi dituntut untuk memiliki tanggungjawab profesional yang besar.

Hasil ini menunjukkan perbedaan dengan hasil penelitian Oktriany, Sulasmono \& Iriani (2018) yang menggunakan model evaluasi yang sama yaitu model Charlotte Danielson. Hasil penelitian tersebut menunjukkan bahwa kinerja guru bersertifikasi sudah berkategori baik pada domain persiapan dan perencanaan, pengelolaan kelas, proses pembelajaran, meskipun pada domain tanggungjawab profesional masih berkategori cukup baik.

Perbedaan hasil penelitian ini dengan penelitian terdahulu diduga antara lain disebabkan oleh masalah akses. Guru pada penelitian sebelumnya berlokasi di pulau Jawa. Guru memiliki akses yang sangat luas untuk meningkatkan kinerja dan mengembangkan diri. Guru dapat memperoleh informasi dan kesempatan yang sangat luas untuk mengikuti kegiatan pelatihan, seminar dan workshop untuk meningkatkan kinerja guru. Sedangkan daerah tempat penelitian ini dilakukan, yaitu di Pulau Sumba, akses guru untuk memperoleh informasi maupun kesempatan untuk meningkatkan kinerja dan mengembangkan diri melalui pelatihan, workshop, dan seminar, sangat minim dan terbatas. Pelatihan yang biasanya diadakan hanya mengutus perwakilan guru dari per mata pelajaran dari setiap sekolah. Pola ini tidak menjamin, bahwa guru yang diutus akan membagikan pengetahuan yang didapat pada pelatihan tersebut. Sehingga guru yang tidak pernah mengikuti kegiatan-kegiatan tersebut tidak memiliki akses untuk mengembangkan diri dan meningkatkan kinerja.

Fenomena di atas juga dapat dijelaskan dengan teori difusi inovasi. Difusi inovasi merupakan proses komunikasi antara anggota sistem sosial (masyarakat) untuk menyebar luaskan inovasi dengan menggunakan saluran tertentu dan dalam waktu tertentu (Sa'ud, 2010:28). Dalam bidang pendidikan, banyak usaha yang telah dilakukan untuk menyebarluaskan inovasi pendidikan. Inovasi dalam bidang pendidikan antara lain dalam hal manajemen pendidikan, metode pengajaran, penggunaan media pembelajaran, pelatihan, dan implementasi kurikulum.

Ada 5 tipe konsumen dalam kecepatannya mengadopsi inovasi, yaitu inovator, pengadopsi awal (early adopter), mayoritas awal (early majority), mayoritas akhir (late majority), dan tipe lambat (laggards) (Robinson, 2009:4). Berdasarkan 5 tipe konsumen tersebut, dapat disimpulkan bahwa guru di Pulau Jawa yang memiliki akses informasi dan akses kesempatan yang luas untuk mengadopsi inovasi pendidikan yang baru, digolongkan dalam kelompok pengadopsi awal (early adopter). Pengadopsi awal (early adopter) merupakan kelompok yang memiliki kemampuan cepat dalam dalam merespon dan membuat keputusan untuk mengadopsi suatu inovasi pendidikan. Sedangkan karena keterbatasan dalam memperoleh informasi maupun kesempatan dalam mengadopsi inovasi pendidikan yang baru, guru yang berada di Pulau Sumba dapat digolongkan dalam kelompok mayoritas akhir (late majorities). Kelompok late majorities merupakan kelompok mayoritas yang cenderung lambat dalam mengadopsi inovasi pendidikan yang baru. 
SIMPULAN DAN SARAN

Simpulan

Berdasarkan analisis hasil penelitian dan pembahasan terhadap kinerja guru bersertifikasi di SMA Negeri 1 Waingapu, maka dapat diambil kesimpulan bahwa kinerja guru bersertifikasi pada domain (1) persiapan dan perencanaan pembelajaran berkategori baik, (2) domain pengelolaan kelas berkategori cukup baik, (3) domain pelaksanaan pembelajaran berkategori baik, dan (4) domain tanggungjawab professional berkategori cukup baik.

\section{Saran}

Berdasarkan kesimpulan diatas maka dirumuskan beberapa saran. Bagi guru yang sudah bersertifikasi diharapkan untuk melakukan perbaikan dan peningkatan kinerja dengan mengikuti berbagai kegiatan seperti pelatihan, melakukan Penelitian Tindakan Kelas (PTK), menulis karya ilmiah, dan berpartisipasi aktif dalam komunitas profesional. Sedangkan saran bagi kepala Sekolah diharapkan untuk melakukan upayaupaya untuk meningkatkan kinerja guru salah satunya dengan mengikut sertakan guru pada pelatihan- pelatihan. Selain itu pengawas sekolah disarankan untuk dapat memberikan motivasi, pembinaan dan pembimbingan berkelanjutan kepada kepala sekolah dalam upaya meningkatkan kinerja guru pada domain perencanaan dan persiapan, pengelolaan kelas, pelaksanaan pembelajaran, dan tanggungjawab profesional.

\section{DAFTAR PUSTAKA}

Agus, M., Taha, Zainuddin., DM, H. M. Ide Said., \& Saleh, Muhammad. (2016). Analysis of Professional Competence of Bahasa Teachers of Senior High School in Jeneponto Regency after Certification. Journal of Language Teaching \& Research, Vol. 7 Issue 1, p66-75. 10p. 1 Chart.
Chang, Mae Chu, Sheldon Shaeffer, Samer AlSamarrai, Andrew B. Ragatz, Joppe de Ree, and Ritchie Stevenson. (2014). Teacher Reform in Indonesia: The Role of Politics and Evidence in Policy Making. Directions in Development. Washington, DC: World Bank. doi: 10.1596/978-0-8213-9829-6

Danielson, C. (2007). Electronic Forms and Rubrics for Enhancing Professional Practice: A Framework for Teaching

Danim, Sudarwan. (2012). Pengembangan Profesi Guru. Jakarta: Kencana.

Erasmus, \& Nicola Vermeulen. (2015). The Use Of Danielson's Framework In Developing A New Fieldwork Training Setting For 3rd Year Occupational Therapy Students From The University Of The Western Cape.South African Journal of Occupational Therapy. Volume 45, Number 2, August 2015

Goe \& Leslie. (2008). Teacher Quality and Stident Achievement. Washington: National Comprehensive Center For Teacher Learning.

Guerriero, Sonia. (2014). Teachers' Pedagogical Knowledge and the Teaching Profession. Paris: OECD Publishing.

Hightower, et.al,. (2011). Improving Student Learning By Supporting Quality Teaching: Key Issues, Effective Strategies. USA: Editorial Projects in Education

Jaedun, A. (2009). Evaluasi Kinerja Guru Bersertifikat Profesional. Makalah Disampaikan Pada Pelatihan "Refleksi Profesi Guru Bersertifikat Profesional,' di kantor Dinas Pendidikan Kabupaten Temanggung, Tanggal 10 Oktober 2009.

Kadir, F. (2014). Keterampilan Mengelola Kelas dan Implemetasinya dalam Proses 
Pembelajaran. Jurnal Al-Ta'dib, Vol. 7 No. 2

Lailatussaadah. (2015). Upaya Peningkatan Kinerja Guru. Jurnal Intelektualita, Vol 3, No 1

Moss, Jonathan Tyler. (2015). The Danielson Model of Teacher Evaluation: Exploring Teacher Perceptions Concerning Its Value in Shaping and Improving Instructional Practice. Submitted in Partial Fulfillment of the Requirements for the Degree Doctor of Education; Seton Hall University.

Mulyasa, H.E. (2013). Uji Kompetensi Dan

Penilaian Kinerja Guru. Bandung: Remaja Rosdakarya.

Mulyasa. (2009). Standar Kompetensi dan

Sertifikasi Guru. Bandung:Remaja Rosdakarya.

Murdadi \& Sulistari. (2015). Dampak Sertifikasi Guru Dalam Peningkatan Kompetensi Profesional di Kalangan Guru SMK Pelita Salatiga. Prosiding Seminar Nasional 2015.
Muslich, Mansur. (2007). Sertifikasi Guru Menuju Profesionalisme Pendidik. Jakarta: Bumi Akasara.

Oktriany, W., Sulasmono, B., \& Iriani, A. (2018). Evaluasi Kinerja Guru Bersertifikasi Dengan Model Charlotte Danielson. Kelola: Jurnal Manajemen Pendidikan, 5(1), 24-36.

Phillips,et.al,. (2014). Teacher Evaluation: Improving the Process. Transformative Dialogues: Teaching \& Learning Journal Volume 7 Issue 3.

Sa'ud, Udin Syaefudin. 2010. Inovasi Pendidikan. Bandung: Alfabeta.

Supriyadi dan Priyastiwi. (2014). Evaluasi Kinerja Guru Pasca Sertifikasi Di UPT Dindikpora Kecamatan Pejawaran Kabupaten Banjarnegara Tahun 2013. Jurnal Riset Manajemen, Vol. 1, No. 1, Hal. 93 - 103

Yusrizal. (2011). Evaluasi Kinerja Guru Fisika, Biologi Dan Kimia SMA Yang Sudah Lulus Sertifikasi. Jurnal Penelitian dan Evaluasi Pendidikan. Volume 15, Nomor 2. 2007). Hlm 7 